\title{
Citrullinemia Type II
}

National Cancer Institute

\section{Source}

National Cancer Institute. Citrullinemia Type II. NCI Thesaurus. Code C150603.

An autosomal recessive sub-type of citrullinemia caused by mutation(s) in the SLC25A13 gene, encoding calcium-binding mitochondrial carrier protein Aralar2. 